\title{
IMPACT OF COOPERATIVE SOCIETIES IN NATIONAL DEVELOPMENT AND THE NIGERIAN ECONOMY
}

ROWLAND A. EFFIOM

(Received 11 August 2014; Revision Accepted 24 September 2014)

\begin{abstract}
The aim of this paper is to examine the social and economic impact of cooperative societies in Nigeria and to investigate into their origin, history, formation and development. Also to be examined is their impact in our rural communities, especially in the grass root, urban and national development. It has been argued that commercial financial institutions such as banks and insurance companies could play greater roles in the advancement of rural development than the cooperative societies. This is so because of the enormous contribution of these financial houses to the rapid, social and economic development of the people, and urbanization. The paper further reviews the various obstacles and challenges confronting the effective performance of cooperative societies in Nigeria, and proffer ways of forestalling these problems. The paper is of the view that as many as these societies may be in form, formation and groups, with their various tags, aims and objectives, government should aid and encourage these organizations to enable them stand and perform effectively since they are all contributive factors in the economic development and growth of Nigeria.
\end{abstract}

KEYWORDS: Cooperatives, Financial Institutions, Collaboration, Membership, Capitalism, Welfare, Consumers, Producers.

\section{INTRODUCTION}

The history of cooperative societies in Nigeria in particular cannot go without reference to the pioneering efforts of great men such as $\mathrm{C}$. F. Strickland, Major F. G. Haig. Captain W. J. W. Chessman, Captain A. G. C. Stainforth, Chief Akinpelu Obiasesan, O. Bateye, J. U. Eka (MBE), Chief A. A. Laditan and R. M. Leslie - the first registrar of cooperative societies in the Eastern region of Nigeria (Odey, 2009). It is interesting to note that after thirty years and more, the benefits and progress of corporations have tremendously affected all the facets and segments of the Nigerian society and economy. Nigeria is an agro-based economy, and it is only natural that agricultural cooperatives should precede any other type of business enterprise in the country. Anytime cooperatives are being mentioned, it starts and ends with Agro allied and agricultural produce. The Agricultural Department with its headquarters in Ibadan organized the Western Region Cocoa Farmers into a group through which better planting and processing methods were taught. In the year 1936, these groups were taken over by the newly formed Cooperative Division of the Agricultural Department for the purpose of organized marketing. In the same year, for the same reason, some other groups engaged in the production of palm produce in Eastern Nigeria were also taken over by cooperatives. The first Thrift and Loan Society was organized by the Abeokuta Catholic Teachers, and the first Thrift and Credit Societies also came into existence during the same period. By the end of 1943, there were already 180 registered cooperative societies, and by the end of the first ten years of inception, cooperative societies had taken firm roots in the country (Odedoku, 1996).

Cooperative society is seen from different perspectives by various scholars,

Rowland A. Effiom, Department of History \& International Studies, University of Calabar, Calabar, Cross River State, Nigeria. 
writers, policy makers and operators. Some of these writers are of the view that the cooperative is a strong organization where different entrepreneurs of cooperators pool their resources together with the view of making profit. Others see it as voluntary economic institution in which members share the earned dividends - the financial benefit that results from doing business with or without profit (Encyclopedia Britannica, 1970).

Lawal (1982), sees this organization as an industrial organization where a number of people may combine as consumers to produce a commodity, the proceeds of which are distributed among the participants. Brown (1986), thinks of cooperative society as a business organization in which a group of individuals who have a common interest, mutually agree to join together to establish this business in order to promote their economic activities like production, distribution or marketing of goods and services, and for the provision of welfare benefits to their members. Of all these definitions, it could be argued that the most embracing of them all is that given by the International Labour Organization - ILO which states that, "cooperative is an organization of persons, usually of limited means who have voluntarily joined together to achieve a common economic end through the formation of a democratically controlled business organization making equitable contribution to the capital required, and accepting fair share of the risks and benefits of the undertaking (ILOWorkers Manual, 1978).

\section{Origin of Cooperative Societies}

The first documented cooperative settlement in human history was that started by the Essence at Eiricydi on the coast of the Dead Sea (Odey, 2009). All of them were free and owned everything in common. In Britain and France, workers, as a result of the impact of the Industrial Revolution spontaneously organized cooperative societies of all sorts, while intellectuals and philanthropists such as Owen in 1858 , and his contemporariesinitiated carefully planned, ideologically motivated corporative communities.

In England, the idea of establishing cooperative organization was mooted and invigorated by Robert Owen in collaboration with his Rochdale pioneers (Obasse, 2012; Ebi, 2014). This organization began in Road Lane, Rochdale in 1844. This particular group of weavers led by Charles Howath met regularly throughout 1844 to discuss on what could be done to improve their working conditions, and of the less privileged workers, artisans, consumers, traders and farmers who were relegated to the background by the capitalist economic system prevalent during this period and arising from the aftermath of the Industrial Revolution.

The Rochdale principles which guided this early cooperative society stipulated the following as its modus operandi: open and voluntary membership; any consumer was free to join, and there were no restrictions to sex, race or social status; democratic control of one man, one vote; political and religious neutrality, limited interest on capital, cash trading at market price, all sales were made at prevailing prices for cash only, patronage dividends proportional to their purchases, and the regular education of their members. Latercooperators added eight more principles which included the first successfully organized cooperative society (Ebi, 2014).

\section{Significance of Cooperative Societies}

Cooperative societies are formed based on certain principles which distinguished them from other business organizations. Odey (2009) asserts that such principles may be based upon the new models of scientific management of businesses and applied economics. Similarly, Olayide (1975) and Whethman (1968) asserts that there is a great distinction between cooperative societies and non-cooperative businesses. The introduction of cooperative societies, Whetman argues, is to remove the evil effects of the capitalist system of production which did not go down well with the common man's aspiration.

Cooperative societies are known to bring about low prices of goods. Goods are bought directly from manufacturers at factory prices and sold to members at controlled prices thereby making their selling prices to be lower than the operating prices in the open market. Cooperatives are managed along democratic lines. Members, for instance, have equal voting rights, equal opportunity to participate in the management and control of the societies and make inputs to policies (Warbasi, 1947).

This organization is noted for its easy formation because it does not require much capital or costly legal procedures to bring it into existence. It has continuity because the death of a member does not affect the continuity of this 
business organization. Advertisement is also not needed in selling the goods and services of the societies since majority of the goods are bought by their members. Education benefits are given to members in areas of production, distribution and buying and selling of goods and services through bulletins. The societies have joint pride of ownership. Thus, they are jointly owned and managed by the members. They take decisions and make policies jointly. This infuses a sense of belonging into the members, propelling them to bring out their best (Draheim, 1952; Epere, 1978; Abasiekong, 1994).

A form of high standard of living is encouraged among members unlike some other known business organizations. For example, the societies provide essential commodities to members at appropriate prices thereby enabling them to consume goods they would ordinarily not have been able to consume or acquire. They also encourage members to save and give credit facilities to the needy members. All these helps the standard of living of members to improve considerably. Cooperatives sell their goods at controlled and stabilized prices, and also regulate the quantity of goods needed. These activities help to fight inflation and deflation. There is good cordial inter personal relationship among members of the society and their employed staff (Omeje, 2003; Digby and Greffon, 1988).

Because of its benefits to the people, in Kenya, groups of farmers on land settlements are encouraged to join cooperatives to undertake purchase, supply, marketing and hulling of such goods and services like cattle, pigs and coffee. In Nigeria, corporative organizationsare also engaged in the collection of savings from weekly wage earners in cities and towns, the selling of foodstuffs, and the erection of shops for its members (Ebi, 2014).

Osagie (1976) is of the view that the cooperative movement if properly organized can facilitate the distribution of goods to all parts of the country at affordable prices. In Nigeria, he argues that part of the goods imported by the Nigerian National Supply Company (NNSC) is distributed through consumer cooperatives. In addition, the cooperative provides avenue through which the masses may be involved in the production and distribution of goods and services. The participation of the masses in the economy of their country, Osagie argues, should lead to social peace and harmony. In other words, the involvement of a reasonably large proportion of the Nigerian business cadre in the equitable distribution of goods and services through the agencies of cooperative organizations should go a long way in ensuring hope, trust, confidence, justice and security within the Nigerian populace and society.

\section{Establishment of Cooperative Societies in Nigeria}

In Nigeria, before the modern cooperatives were put in place, there existed cooperative societies that were indigenous to the local people. These includes the labour clubs, the contribution clubs, and the indigenous and traditional farmers' societies which functioned at nearly all villages and community levels (Obasse, 2012; Crowder, 1973).

The modern cooperative movement in Nigeria started when C. F. Strickland was appointed in 1933 to look into the possibility of introducing cooperative societies into the country. Strickland's report came out in 1934, and reported that cooperatives be established in Nigeria for the following reasons: to eliminate exploitation by middle men; for producers to deal directly with the entrepreneurs, producers and buyers; for members to benefit from the extension of the Department of Agriculture; other requisite know-how to produce high quality cotton, cocoa, and palm produce to get higher prices; to provide production credit to members; and to do away with high interest loans. To promote cooperative spirit in a social system that already provides the fundamental rudiments of cooperatives (Oshuntogun, 1981; ljere, 1975).

Sequel to Strickland's report, the first Cooperative Ordinance in Nigeria was passed in 1935. Later in 1936, Faulker was appointed the Registrar of Cooperatives and the control of cooperatives gradually shifted from the Agricultural Department, and it empowered the registrar of cooperatives to register, inspect, audit, hold inquiries and settle disputes and liquidate unsuccessfully registered cooperatives.

The ordinance was in operation until the three regional governments of the east, north and the west) started adopting their own cooperative society laws. Before this time, there was a Cooperative Federation Limited, having its headquarters at Ibadan. However, as from 1952, onwards, each of the regions had her own cooperative department under different registrars; and Ibadan ceased to be the head-office of Nigerian cooperative societies. In 1963, the 
cooperative societies in the Federal Territory of Lagos and the Mid-Western states respectively broke away and became autonomous in the creation of more states in 1967 and 1970 respectively (Oshuntogun, 1981; ljere, 1975).In 1974, the Federal Military Government promulgated decree no. 5 for the establishment of a Cooperative Development Division in the Federal Ministry of Labour for the appointment of supporting staff (Oshuntogun, 1981; ljere, 1975).

It can at this juncture, be argued that cooperative societies occupy a significant place in the cooperative movement. Their importance is seen in their ability to meet the much needed cheap institutional credit needs of members, especially farmers and small scale business men who hardly had access to bank loans. This cooperation does not demand for the type of collaterals which other lending institutions usually and normally require before granting loans. Thus, credit cooperatives enable their poor members to finance and float projects with ease (Umana and Ikpeazu, 1980).

\section{Forms of Cooperative Societies in Nigeria}

There are a proliferation of cooperative societies operating in nearly all the sectors of the Nigerian economy. Put briefly, this would include the Consumers Cooperative Societies which are organized by consumers who pool their resources together in order to advance their interest in retail purchases. They own shops, buy consumer goods in bulk from manufacturers at factory prices and retail them to members at controlled prices. Any profit made is returned to members as patronage rebates. There are also theProducers' Cooperative Societies, here, Producers, or Farmers' Cooperative Societies are organized by farmers or producers who pool their resources in order to engage in large-scale production and market their products themselves. We also have the Credit and Thrift Cooperatives. These according to Omeje (2003) are usually organized by members like traders, artisan and peasant farmers who contribute money into a common fund in order to raise investment, finance and distribute same as soft loans to members. So, the main aim of this type of cooperative society is to encourage savings among members and also offer credit facilities to members to enable them engage in economic activities. The society usually exist with a specific name such as Nigeria Union of Teachers, Road Transport Workers' Union, Credit and Thrift
Cooperative Society (Omeje, 2003; Adesina, 1998).

There are also in existence the MultiPurpose Cooperative Societies. These are organized by people who pool their resources together in order to combine different activities such as marketing of consumer goods, credit and loans and so on. The society usually exist with a specific name such as Consumers' Multipurpose Cooperative or Producers Farmers. The term "Multi-Purpose" allows the society to undertake any type of cooperative activity that is profitable in the interest of the society and its members. There are the Industrial Cooperative Societies. These industrial or production cooperative societies are organized by individuals who engage in specialized, skilled activities such as carpenters, painters, masons, tailors and panel beaters, plumbers, etc. Members of the same skills come together to mobilize funds needed for their business investment and expansion (Umeje, 2003; Baker, 1991). It should also be noted that these cooperative societies functions from our rural communities to the local government levels, to the urban centres, having immense impact within government circles and establishments, and vibrating in nearly all of our institutions of higher learning, the industrial and financial sectors inclusive, and on all sectors of the Nigerian economy. Martin (1971) opines that the aims, goals and objectives of these organizations are all the same, namely, to serve the interest of the common man.

\section{Charges, Functions and Impact on National Development}

Over the years, there have been significant shifts in the theory of development, and, there is yet no complete agreement on what development really is, and what propels it. One view which seems to summarise its salient features is that which defines development as essentially allocating resources for achieving greater socially satisfying ends (Fetbow and Elsworth, 1999; Aziz, 1978).

It is evident from available sources and history that cooperative organizations had by their charges and functions impacted immensely on national development. For example, they are not only charged with developmental activities such as agriculture, transportation and credit creation, they are also catalyst for poverty reduction through the economic and social progress of their members and employees. They 
achieve this by stimulating their economic activities and enhancing the social fabric of the communities in which they operate (Lawal, 1982; Crowder, 1973).

The organization also stands out as an employment generation forum. This is so because it has to create, improve and protect the income and employment opportunities of its members by providing the limited individual resources of members to create business enterprises that enables members to participate in production, profit sharing, cost-saving or risk taking activities (Adesina, 1998; Crowder, 1973).

It could further be argued that many cooperatives played the role of becoming buying agents of the marketing boards. They handled a considerable percentage of the supply of cash crops such as groundnuts, cocoa, cotton, palm kernel, palm oil, etc. from the suppliers to the Marketing Boards particularly from the years 1947 to 1961. See tables 1 and 2.

TABLE 1: SHOWING THE SUPPLY OF GROUNDNUTS, COCOA AND COTTON BY COOPERATIVES TO THE MARKETING BOARDS IN NIGERIA FROM 1947 TO 1961.

\begin{tabular}{|l|l|l|l|}
\hline YEAR & GROUNDNUTS $(£)$ & COCOA(£) & COTTON $(£)$ \\
\hline $1947 / 48$ & $4,267,600$ & $9,201,800$ & \\
\hline $1948 / 49$ & $6,137,000$ & 420,600 & \\
\hline $1949 / 50$ & $2,444.000$ & $6,479,400$ & $1,185,900$ \\
\hline $1950 / 51$ & $3,002,700$ & $10,549,600$ & $2,077,600$ \\
\hline $1951 / 52$ & $4,851,300$ & $1,438,700$ & $1,028,500$ \\
\hline $1952 / 53$ & $3,505,800$ & $-87,300$ & $1,440,000$ \\
\hline $1953 / 54$ & $3,588,600$ & $5,620,000$ & $1,236,000$ \\
\hline $1954 / 55$ & $-133,100$ & $5,025,800$ & $1,672,100$ \\
\hline $1955 / 56$ & $1,075,500$ & $-4,169,000$ & 500,700 \\
\hline $1956 / 57$ & $3,075,000$ & $-1,266,000$ & 230,700 \\
\hline $1957 / 58$ & $-4,041,500$ & $4,916,300$ & $-949,500$ \\
\hline $1958 / 59$ & $-1,970,200$ & 7830,600 & $-983,300$ \\
\hline $1959 / 1960$ & 828,400 & $1,098,600$ & $-990,500$ \\
\hline $1960 / 1961$ & 887,400 & $-3,752,900$ & $-1,176,500$ \\
\hline Total & $25,743,300$ & $43,480,300$ & $4,272,300$ \\
\hline
\end{tabular}

Source: Calculated from figures obtained from the Department of Trade and Cooperatives Calabar, during field work. 
TABLE 2: SHOWING THE SUPPLY OF PALM KERNEL AND PALM OIL BY COOPERATIVES TO THE MARKETING BOARDS IN NIGERIA FROM 1947 TO 1961.

\begin{tabular}{|l|l|l|}
\hline YEAR & PALM KERNEL $(£)$ & PALM OIL $(£)$ \\
\hline 1947 & $2,433,200$ & 995,400 \\
\hline 1948 & $2,550,600$ & $2,511,600$ \\
\hline 1949 & $4,512,200$ & $1,996,900$ \\
\hline 1950 & $2,553,700$ & $2,301,300$ \\
\hline 1951 & $4,818,200$ & $2,508,300$ \\
\hline 1952 & $4,044,500$ & $-4,647,100$ \\
\hline 1953 & $2,538,400$ & $-2,292,000$ \\
\hline 1954 & $1,645,100$ & 377,700 \\
\hline 1955 & 573,100 & $1,694,800$ \\
\hline 1956 & 260,600 & $1,694,800$ \\
\hline 1957 & $-257,900$ & 263,500 \\
\hline 1958 & 635,000 & 853,100 \\
\hline 1959 & $5,780,400$ & 6,000 \\
\hline 1960 & $4,379,200$ & 195,700 \\
\hline 1961 & 562,100 & $3,169,200$ \\
\hline Total & $36,978,200$ & $10,848,800$ \\
\hline
\end{tabular}

Source: Calculated from figures obtained from the Department of Trade and Cooperatives Calabar, during field work.

In Table 1, from 1947 to 1948, and from 1948 to 1949 , while groundnuts and cocoa were sold to the Marketing Board at reasonable prices, cotton production and sale made no impact, although from 1948 to 1950 , its production picked up considerably up to $1960 / 1961$ marketing period. Prices for groundnuts fell from 1959/60 to $1960 / 61$, while that of cocoa also fell in 1952/53 marketing period. That of cotton also fell from 1955 to 1959/60. In table two, the production and sale of palm kernel fell from 1955 to 1958 , while that of palm oil fell from 1957 to 1960. The fluctuation in the production and sale of these cash crops may not be far from fluctuations in the global market prices, and the adverse effects of climatic factors and storage of these cash crops.

The cooperative marketing societies of the former Northern Nigeria, purchased 24,600 tons of cotton; 5,410 tons of palm kernels and 670 tons of cocoa during the $1962 / 63$ season. As far back as 1953, the Association of Nigerian Cooperative Exporters marketed 9,700 tons of cocoa, almost one-tenth of the entire crop, 4,300 tons of palm kernel, 150 tons of palm oil, 1,500 tons of copra and 500 tons of coffee. The aggregate working capital of the Association had reached $£ 300,000$ by the end of 1953 whilst the turnover in 1953 was £2million (Olaniyan, 1971).
The habit of thrift and savings among the numerous petty traders, craftmen, semi-skilled and unskilled has been encouraged by the cooperative thrift and savings societies. The Cooperative Supply Association which use the apex organization of the consumers cooperative movement gave financial assistance to building societies, craft societies and provided funds for short term production credit to cooperative societies. Apart from Nigeria, the cooperative system in West Africa has aided the accumulation of national resources and the promotion of agricultural export crops and thereby helping to increase the volume of foreign exchange which is needed for national growth and economic development (Olaniyan, 1971).

Sanjor (1992) and Adesina (1998) opines that cooperative societies serve as engines of social integration and cohesion in the face of inequalities in social capabilities by empowering and giving voice to the poor and to the needy as well as the marginalized groups; and by promoting the organization of federation and alliances. In addition, these organizations play important roles in the global economy as well as in the fostering of peace building among human communities and nations of the world (William, 1978). 
It could be argued that from the point of view of their operational framework, cooperatives work towards fair globalization - one that is fundamentally inclusive, sustainable and people oriented. They achieve this by creating business entities that promotes solidarity among the people, greater accountability, deep partnership and fair roles and standards that offer equitable opportunities for all (Obasse, 2013, Odey, 2012; Sanjor, 1992).

Cooperatives operate as a sure source of loans for members. The existence of cooperative organizations have broken the age long lending monopoly of money lenders and other financial houses with their prohibitive interest rates which does more harm than good to the beneficiaries (William, 1978).

Cooperatives do not only instill savings habits in members, they also have greater synergy among its members. This has metamorphosed cooperatives to own large industrial and distributive trades. A typical example is in Kenya where cooperatives own railway transport businesses and many textile factories. In Calabar, the capital city of Cross River State, the University of Calabar multipurpose cooperative is a proud owner of landed properties, estates and assets. It should also be mentioned that western Nigeria has gone steps further with the establishment of a cooperative school where auditors and inspectors are being trained to audit and inspect the activities of various cooperative societies to avoid fraud, misappropriation and maladministration (Famoyin, 1973; ljere, 1992)

\section{Cooperatives as Engines of Sustainable Economic Growth}

It could still be argued that the promotion of cooperatives can lead the renaissance for the revival of global economy. This view has been expressed by the ILO (Olayinka, 2014). Rhyder (2014) also posit that cooperatives are the ones that are more relevant than ever if the world looks ahead at the development challenges and opportunities the job faces over the coming decades. Cooperatives, he further argues, can offer the chances of making extreme poverty and deprivation history to secure social inclusion, and to reconcile economic and social objectives. Thus, these organizations are capable of creating wealth for the poor, creating jobs for the millions of the unemployed the world over, checking poverty and hunger, and above all, achieving global prosperity.

Cooperatives and other social economic enterprises have shown that they have the capacity to reach many of the poor and excluded that are neither conventional markets for goods and services nor by governments (Olayinka, 2014). A recent study by the ILO and the International Cooperative Alliance (ICA) titled "Cooperatives and Sustainable Development Goals" highlights the contributions that cooperative enterprises are making to sustainable development and their potential to do much more from creating employment and enhancing gender equality, providing clean energy and financial inclusion to ensuring food security and extending social protection.

Many of the working poor, the hungry and the excluded are the rural workers, often small holder farmers. Olayinka (2014) opines that, cooperatives have an outstanding track record of overcoming multiple forms of exclusion in rural areas, but not only there, cooperatives are present in all sectors of Nigeria and world economies and are adaptable to a range of contexts. They thus respond to the triple bottom line of sustainable development, economic development, social justice, and environmental protection.

Cooperatives are very much enterprises of the future which play an essential role in complementing conventional markets and government action. This fact is acknowledged explicitly in the outcome document of Rio +20 conference titled "The Future We Want" (The Guardian, 8 July, 2014). The international community should bear this in mind when setting out the strategies and the means through which the sustainable development goals can be realized. The ILO in its ensuring collaboration with cooperative movements should be ready to help and to ensure that cooperative enterprises find their place as enterprises of the future and motor for social inclusion and sustainable development (ILO, Annex I, 1975).

\section{Challenges}

There are a plethora of problems that seem to mitigate and hamper the effective performance of cooperative organizations in Nigeria. Writers and economists such as J. U. Umana, F. O. Ikpeazu, R. H. Greffon and others have written extensively on cooperatives and have examined the weaknesses attending these 
organizations worldwide shortly after the "First All Nigeria Cooperative Seminar" held in Lagos in 1980 (Umana and Ikpeazu, 1980).

The first major challenge has been the need to acquire and maintain adequate equity and capital to help finance growth, and provide an increased working capital. Production for example in the agricultural sectors has been experiencing boom, the need therefore arise to add assets to serve and meet the needs of agricultural production (Cobia, 1989). The reason here is that most members are low income earners and as such the capital they can raise is usually inadequate.

Cooperatives exhibit poor management styles. This is so because members are elected into the management committee not on the basis of managerial expertise and experience but on the bases of their popularity. This does not augur well for the organization which is supposed to have skilled and talented leadership (Adesina, 1998; Robin, 1976). This scenario has in no small measure led to the continual dwindling returns on their investments. This has as a matter of fact ended the original focus of the pioneers.

Low financial base of members is yet another constraint on cooperatives. This challenge stem from the financial background of members (Enikanselu, 2005). Given this scenario, cooperatives are placed on financial straight jacket which frustrates their efforts of hitting their limelight. They have been unable therefore to engage qualified staff to carry out effective documentation of their activities. The result is colossal losses suffered by cooperatives with concomitant ebbing of their financial base.

Illiteracy is also a problem, because, majority of cooperatives members are illiterates who do not understand what is happening when it comes to paper work. This dampens the morale of the illiterate members and thus affects their contributions in the society. The organization also faces excessive government control that tend to stifle the societies. Poor performance is another weakness. Inefficiency and incompetence of committee members bring poor performance into cooperative societies. It is not a good source of revenue to government since the society enjoys tax-free profits (Robin, 1975).

They are confronted with delay in decision making. In fact, many members are involved in decision and policy making and this creates delay since all the committed members are consulted before decision and policies are made. There is also divided loyalty in the rank and file of cooperative members. Thus, committee members tend to pay more attention to their individual businesses than the cooperative business. Most times, they work in the cooperative business on part-time basis. The organization has limited expansion. Inadequate capital limits expansion possibilities in cooperative societies (Robin, 1975).

Omeje (2003), points to lack of personal initiative as one of the banes of cooperative societies. This lack of initiative by members of the management committees reduces the development entrepreneurship among cooperators. Cooperatives also have difficulty in loan recovery because of poor yield, crop failure or debtor dishonesty. There are also high embezzlement rate in cooperative societies. Their funds are often embezzled by some dishonest cooperators who use the fund for their selfish interest. Disloyalty is another challenge of the societies. Some members tend to be disloyal to the society by not paying their dues and levies (Omeje, 2003).

\section{Lessons so far learnt from Cooperative Societies in other West African States}

This study proffers that cooperatives provides for the welfare benefits of its members. It also creates an opportunity for self-help through mutual help. In Nigeria, the then Department of Agriculture also influenced the formation and promotion of cooperative societies. It undertook to establish credit societies in urban and rural areas and provided working capital (Olaniyan, 1971; Cobia, 1989; Crowder, 1973; Hopkins, 1975). In 1951, there were some 310 marketing societies which engaged mainly in cocoa. The societies were affiliated to the Association of Nigerian Cooperative Exporters. The number of cooperatives rose to 500 in 1952 and by 1953 the Cocoa Cooperative Marketing Association had a turnover of £2million. The societies as earlier mentioned, encouraged their members by granting them short credit facilities which they could not easily obtain from the banks. The 1951 constitutional reforms led to the dissolution of the Nigerian Cooperative Federation in 1952 as a result of which the then Western and Eastern region set up regional cooperative unions (Olaniyan, 1971).

In Ghana, the development of the cooperative movement has almost the same history as that of Nigeria. The Department of 
Agriculture was responsible for promoting cooperative activities between 1929 and 1944. By 1943, there were 302 cooperative societies for marketing cocoa. A separate Department for the promotion of cooperative societies was established in 1944. In 1953, the Cooperative Marketing Association marked some 47,423 tons which was approximately 19.5 percent of the total crop of the territory. Apart from Cocoa Cooperative Marketing Societies, there were others which dealt with fruits, vegetables, rice and agricultural products. By 1953, the credit societies were grouped under the Gold Coast Cooperative Bank whose principal function was to finance the operation of the Gold Coast Cooperative Marketing Association and the Gold Coast Cooperative Wholesale Establishment Limited. The bank had a working capital of $£ 478,000$. By the end of 1953 , the cooperative Wholesale Establishment went into voluntary liquidation.

In Sierra Leone, an ordinance was passed in 1939 for the formation of cooperative societies. By 1953, there were about 125 cooperative societies with 5,207 members. The total turnover of the societies was $£ 72,000$. Remarkably, the producer marketing societies performed well in improving the quality of the product. In addition, there were credit societies which granted loans to members.

The Cameroon then under the British Trusteeship had a total of 45 cooperative societies in 1952. Thirty-two of them were for marketing produce. The Cameroon Cooperative Exporters Limited was formed in 1953 to coordinate all cooperative societies' activities in the country. It helped to improve the performance of cooperative societies as a result of which they had a turnover of $£ 120,000$ in 1953.

Unlike the British colonies where the development of cooperative societies was encouraged by British administration, the French government did not actively encourage the projection of the cooperative system in her territories. But after the Second World War, agricultural cooperative societies were established by legislation in Senegal, Upper Volta, Niger, Guinea, and in Dahomey. Since then, there had been a considerable increase of cooperative societies in French West Africa.

On the whole, cooperative societies could be noted as veritable engines of economic development and human capacity building among the governments of West African States.
Their impact is also felt from the rural to the urban areas. The cooperative societies in Nigeria has aided the accumulation of natural resources and the promotion of agricultural export crop and thereby helping to increase the volume of foreign exchange which is needed for economic development and transformation. Therefore, cooperatives can be more effective by functioning hand in hand with government approved programmes for the benefit of the people.

\section{CONCLUSION}

Although cooperative societies in this country have witnessed tremendous successes, they have some retrogressive issues that tend to often stall the good will, progress and prosperity of these societies. Some of the issues listed in this paper include poor management and lack of trained staffs, insufficient financial resources on the part of members, dishonesty, corruption, gang up by the capitalists to frustrate cooperative advancement and growth in order to protect their own business (Kidd, 1968), and the absence of felt need among members essential to the survival spirit of the cooperatives.

\section{RECOMMENDATIONS}

It is hereby suggested that cooperative societies at all levels should be strengthened, controlled and owned by cooperative members themselves without undue government interference. Thus, government presence in this sector of the Nigerian economy should be limited by all means to the training of manpower for cooperatives and developing national policies that will make it easier for cooperative members to group themselves properly and achieve maximum breakthroughs in their organizations.

Government should as a matter of urgency and priority review the cooperative laws and regulations of the country from time to time in order to meet the desired needs and aspirations of the cooperatives. There is also the need to review the loan policies of all cooperative financing agencies such as the State Cooperative Banks, the Nigerian Agricultural Cooperative and Rural Development Bank, and create more rural branches of these banks throughout the country.

Government should establish cooperative units under the various Local Government Departments of Agriculture which will work hand in hand with the state and the federal agencies concerned with cooperative 
activities. It is also advisable that government should be engaged in a wide and large scale campaign in order to educate members and non members of cooperatives about the contributions of cooperatives to the social and economic well being of the common man.

All impediments militating against the development of cooperative societies in Nigeria should be expunged by government. In short, government should have a hand in the general development and sustainability of cooperative societies in the country since these organizations have glaring positive impact on the generality of the Nigerian populace and on socio-economic and national development.

\section{REFERENCES}

Abasiekong, E. M., 1982. Integrated Rural Development in the Rural World. New York.

Adeniyi, Oshuntogun, Ndaniusa, Majindad and Bawo Olufokunbii., 1981. "Marketing and Distribution of Food Crops in Nigeria through the Development of Farmers' Cooperatives: A Strategy of Approach for given Revolution". Federal Department of Agricultural Cooperatives, Lagos.

Adesina, O., 1998. "Essential Information on Cooperatives Credit Facilities", Ibadan, Dacprints.

Aziz, Sartaj, 1990. Rural Development: Lessons from China, Macmillan press.

Adeniyi, Oshuntogun., 1988. "Development of Farmers' Co-operatives: A Strategy of Approach for the Green Revolution" Federal Department of Agricultural CoOperatives, Nigeria Trade Journal, Vol. 25, No. 6, 1988, Lagos.

Brown., 1986. Quoted in Odey Abubakar, "Impacts of Cooperative Societies in Akwa Ibom."

Crowder, Michael., 1973. West Africa Under Colonial Rule. London, Hutchinson.

Cobia, David., 1989. Cooperative in Agriculture, New Jersey, Englewood Cliffs, Prentice Hall.
Digby, $M$ and Greffon, R. H., 1988. "Cooperative Marketing for Agricultural Production". Food and Agricultural Organization of the United Nations (FAO), Italy.

Draheim, G., 1952.The Cooperative Society as a Form of Enterprise, London, Geothingen.

Osagie, E., 1976. Elements of Economics. Benin, Umeh Publishers.

Ebi, Boniface., 2000."Notes on Cooperative Societies". Department of Cooperative Societies, Calabar, Cross River State.

Ekpere, J. A., 1978. "International Cooperative Alliance" in Review of International Cooperative, Vol. 71, No. 4.

Enikanselu, S. A., Akanji, S. O and Fasseyiku, I. O., 1973. Principles and Economics of Cooperatives (Ed). Detrade, Lagos.

Famoyin, V. O., 1973. Foundations of Economics of West Africa. Ilesha.

Hopkins, A. G., 1973. An Economic History of West Africa, London, Longmans.

ljere, M. O., 1976. "Cooperative Business Enterprise, Maryland, Lagos.

ljere, M. O., 1978. New Trendsin African Cooperative: The Nigerian Experience, Enugu, Fourth Dimension Publishers.

International Labour Organization (ILO)., 1991. Annex I printed Publications and Mimeographic Documents. Cooperation and Small-Scale Industries Dinsum, Geneva.

International Labour Organization (ILO)., 1978. Geneva, Workers Manual.

Jetbow, W. W and Elsworth, R. H., 1993. Agricultural Cooperation in the United States, Prentice Hall, New York.

Joab, Baker., 1991. Economics of Cooperative Society. Macmillan, New York. 
Kidd, Ayo., 1968. Factors affecting farmer's response in western Nigeria, Ondo, CSNRD. Pp. 10-12.

Obasse, E. Okorn., 2012. "The Impact of Agricultural Cooperative Society in National Development. A Case Study of Obubra Local Government Area". An unpublished B. A. Research Project submitted in the Department of History and International Studies, University of Calabar.

Odedoku, M. O and Udokogu, P. C., 1996. Commerce for SSS2. Ibadan: Longmans, Nigeria.

Odey, B. Abubakar., 2009. "The Impact of Cooperative Societies in Akwa Ibom State. A case study of Use Ikot Oku Multi-Purpose Cooperatives Society Limited in Ibiono L. G. A. between 19902002". An Unpublished B. A. Research Project Submitted to the Department of History and International studies, University of Calabar.

Olayide, S. O., 1975. Elements of Rural Economics, Ibadan.

Olayinka, Collins., 2014. "ILO seeks Adoption of Cooperatives for Sustainable Development," "in The Guardian Newspaper, www.ngrguardiannews.com, Tuesday, July 8, 2014.

Omeje, P. Eke., 2014. The Mastery of Economics, Masckho - Ricckho, Lagos.
Olayide, S. O., 1975. Economics for a Developed World. London.

Riot+20 Conference 2014. "The Future We Want" in the Guardian Newspaper, 8 July.

Robin, H., 1976. "The Lessons we have Learned in Cooperative". American Cooperative Journal.

Sanjor, A. F., 1992. "Nuts and Bolts of Community Development. Delta Esekin Services in Nigeria.

Umana, J. U. and Ikpeazu, F. O., 1976. First All Nigeria Cooperative, Lagos.

Warbasi, J. P., 1947. Cooperatives in Democracy. Hapers and Brothers, New York.

Whetman., 1968. Quoted in Ebi Boniface "Notes on Cooperative Societies," Department of Trade and Cooperatives, Calabar, 2000.

Wikipedia Agricultural Cooperative ...Retrieved October 22, 2011: http://wikipedia.org//wiki/agriculturalcoop $\underline{\text { erative }}$

William, S. K. T., 1978. "Rural Development in Nigeria". University of Ife. 